\title{
Pengaruh Kualitas Dan Pemasangan Kabel Suplai Pada Peralatan Rumah Tangga Sesuai SNI IEC 60335-1:2009
}

\section{Effect of Supply Cord Qualities and Installation On Household Appliances According to SNI IEC 60335-1:2009}

\author{
Mohamad Marhaendra Ali \\ Kementerian Perindustrian \\ Balai Riset dan Standardisasi Industri Surabaya \\ Surabaya, Indonesia \\ ali_industri@yahoo.com
}

\begin{abstract}
Abstrak - Pemasangan kabel dan kualitas isolasi kabel pada peralatan rumah tangga harus tahan tekanan listrik terhadap gaya tarik dan torsi dan aman terhadap arus hubung singkat. Pengujian dilakukan sesuai klausal 23 tentang pengkawatan internal dan klausal 25 tentang sambungan suplai dan senur fleksibel eksternal pada produk kipas angin, pompa air dan seterika listrik. Metode pengujian yang digunakan adalah inspeksi pengawatan dalam, kekuatan dielektrik bahan isolasi, luas penampang konduktor, uji tarik dan torsi. Topik penulisan ini membahas faktor penyebab kegagalan pengujian dan cara memperbaikinya. Hasil pengujian menunjukkan bahwa piranti yang baik mempunyai pengawatan dalam yang memadai terhadap bagian tajam, bagian bergerak dan panas. Selain itu kabel fleksibel eksternal menggunakan standard kabel yang dipersyaratkan sesuai arus dan berat pirantinya, mempunyai jangkar kabel yang kuat dan pergeseran kabel $<2 \mathrm{~mm}$ setelah uji tarik dan torsi sehingga terjamin keselamatan pengguna selama penggunaan normal.
\end{abstract}

Kata Kunci: Uji tarik, uji torsi, kekuatan dielektrik, pengawatan dalam, kabel listrik, kipas angin, pompa air, seterika listrik

\begin{abstract}
Cabling and cord insulation qualities on household appliances should withstand electrical pressure against pull force and torque and are safe against short circuit currents. The test is carried out in accordance with clause 23 about internal wiring and clause 25 about supply connection and external flexible cords on fan, water pumps and electric iron. Test methods used are internal wiring inspection, dielectric strength of insulation material, conductor of cross section area, pull test and torque test. This topic discusses the causes of test failure and how to fix it. The test results indicate that a good device has adequate internal wiring of sharp, moving parts and heat. In addition, the external flexible cord use standard cables required according to current and weight of the equipment, have a strong cable anchors and shifting cables $<2 \mathrm{~mm}$ after pull test and torque to ensure user safety during normal use.
\end{abstract}

Keyword : pull test, torque test, dielectric strenght, internal wiring, supply cord, fan, water pump, electric iron

\section{PENDAHULUAN}

Kabel adalah peralatan pokok dalam instalasi yang berfungsi menyalurkan energi listrik ke peralatan yang menggunakan energi listrik merupakan peralatan yang paling rentan dalam hal keamanan instalasi. Apabila kita perhatikan di televisi atau media lainnya, cukup sering terjadi kebakaran rumah yang disebabkan oleh hubungan pendek arus listrik (hubung singkat). Hal ini bisa terjadi karena sambungan kabel yang kurang baik ataupun buruknya kualitas isolasi kabel. Untuk itu diperlukan kehati-hatian dalam hal memilih kabel yang akan digunakan. Sedangkan untuk mengantisipasi kerusakan isolasi kabel, diperlukan pengetahuan tentang faktor-faktor penyebab kerusakan isolasi dan seberapa besar faktor-faktor tersebut berpengaruh terhadap kerusakan isolasi [1].

Dalam rangka melindungi konsumen dari produk yang tidak aman dikonsumsi, pemerintah harus menyatakan keberpihakannya terhadap keamanan konsumen melalui kebijakan-kebijakan. Saat ini kebijakan yang terkait dengan keamanan produk tersebar di berbagai sektor baik secara eksplisit maupun implisit yang meliputi antara lain pangan, bahan bangunan, kendaraan bermotor beserta komponenkomponennya, mainan anak-anak, alat-alat listrik, elektronika dan lain lain [2]. Produk kelistrikan memiliki berbagai ragam dan jenis, kita mengenal produk kelistrikan instalasi seperti kabel, tusuk kontak, kotak kontak, sakelar, ELCB/RCCB/GPAS hingga produk . seperti kipas angin, lampu, lemari pendingin, pompa air dan televisi. Hingga Agustus 2012 setidaknya terdapat 30 regulasi yang memberlakukan wajib SNI produk kelistrikan [3]

Isolator merupakan salah satu peralatan listrik yang berfungsi memisahkan secara elektris dua buah penghantar atau lebih sehingga tidak menimbulkan kebocoran arus atau gradien tinggi berupa lompatan api (flashover). Dilihat dari fungsinya isolator mempunyai fungsi sebagai penyangga 
(solid support), pengisi (filling media) dan penutup (covering material) [4].

Suatu konduktor penghantar listrik umumnya dilapisi oleh suatu bahan isolator listrik. Isolator listrik ini dapat menghentikan pelepesan panas akibat dari adanya aliran listrik. Telah diketahui bahwa suatu kawat penghantar listrik dapat menjadi panas setelah mengantarkan arus listrik. Selanjutnya akan dianalisis model dari hilangnya panas pada penghantar listrik setelah sumber listrik dihentikan alirannya. Dikontruksikan sebuah model aliran panas sederhana dari suatu penghantar listrik dengan panjang L dapat dilihat pada gambar 1 dibawah ini [5]

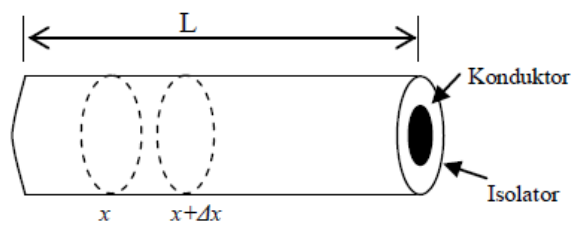

Gambar 1. Penampang Konduktor Listrik

Tegangan tembus merupakan tegangan minimum yang dapat merusak bahan isolasi. Bahan isolasi dikatakan tembus apabila pada bahan tersebut mengalir muatan listrik negatif (elektron). Mengalirnya elektron-elektron secara terus menerus akan menimbulkan arus bocor pada permukaan bahan isolasi dan akan mengurai ikatan kimia bahan isolasi. Akibatnya, timbul kerak konduktif (jejak arus) yang dapat membentuk jalur konduktif dan menimbulkan tekanan elektrik yang berlebihan pada isolasi. Apabila isolasi/ dielektrik tersebut tidak dapat menahan tekanan listrik dan berubah sifat menjadi konduktif, maka bahan isolasi tersebut telah tembus listrik (breakdown). [6]

Kekuatan mekanik bahan isolasi adalah kemampuan dari suatu bahan untuk menahan beban yang datangnya dari dalam atau dari luar, yang merupakan beban tarik dan beban geser. Suatu bahan jika ditarik dengan suatu gaya tarik yang bertambah secara perlahan-lahan, maka bahan tersebut akan putus pada gaya tarik tertentu [7]

Permasalahan yang sering terjadi adalah kualitas bahan konduktor, isolasi kabel dan pemasangan sambungan kabel yang kurang baik sehingga pengawatan dalam dan kabel flesibel eksternal tidak memadai saat terjadi tekanan listrik pada penggunaan normal.

Kualitas mutu produk dan cara pemasangan kabel suplai pada peralatan listrik rumah tangga dapat mempengaruhi keselamatan pengguna. Hal ini dikarenakan kabel suplai berpotensi mengalirkan arus listrik dan rentan terhadap bahaya hubung singkat sehingga perlu kajian terhadap standard uji tentang kualitas kabel suplai dan solusi terhadap kegagalan uji untuk menghindari resiko yang dapat membahayakan konsumen saat penggunaan piranti tersebut.

Penentuan parameter yaitu hasil inspeksi pengawatan dalam, kekuatan dielektrik bahan isolasi, luas penampang konduktor, uji tarik dan torsi yang hasilnya menjadi acuan kelulusan peranti berdasarkan standar yang berlaku menjadi state of the art pada penulisan ini. Tujuan penulisan ini adalah mengetahui kemampuan peranti rumah tangga terhadap pengujian yang dilakukan dan mencari faktor penyebab dan parameter yang perlu diperhatikan agar piranti tersebut aman dalam penggunaannya

\section{BAHAN DAN METODE}

Piranti peralatan listrik rumah tangga harus mempunyai instalasi pengkabelan yang memadai dan aman terhadap pengaruh tekanan listrik pada penggunaan normal sesuai persyaratan umum keselamatan SNI IEC 60335-1:2009 klausal 23 tentang pengkawatan internal dan klausal 25 tentang sambungan suplai dan senur fleksibel eksternal [8]. Peralatan yang digunakan adalah :

- Withstanding (W/I) Autotester

- Aluminium foil

- Vernier caliper

- Creepage Distance Tester.

- Push pull scale

- Torque gauge

Pengujian ini dilakukan terhadap piranti kipas angin, pompa listrik dan seterika listrik. Persyaratan piranti yang dipersyaratkan sesuai SNI IEC 60335-2-80:2009 tentang persyaratan khusus untuk kipas angin [9], SNI IEC 60335-241:2009 tentang persyaratan khusus untuk pompa listrik [10] dan SNI IEC 60335-2-3:2009 tentang persyaratan khusus untuk seterika listrik [11]. Semua piranti tersebut mempunyai ketentuan yang hampir sama

Metode dan teknik pengukuran untuk inspeksi pengawatan dalam adalah :

- Periksa jalan masuk kabel harus halus dan terbebas dari sudut yang tajam atau dilengkapi dengan bushing

- Pengawatan terhindar dari sentuhan benda bergerak dan panas yang melebihi spesifikasi dari isolasinya.

- Tidak dapat menyentuh permukaan yang tajam. Apabila konduit logam fleksibel harus dilengkapi dengan insulating sleeve.

- Pipa logam fleksible tidak menyebabkan kerusakan pada isolasi konduktor.

- Isolasi dasar pada senur yang digunakan di pengawatan dalam untuk isolasi listrik sesuai dengan IEC 60227 atau IEC 60245

- Konduktor yang berisolasi gabungan dari warna hijau/kuning hanya digunakan untuk konduktor pentanahan.

- Kawat aluimunium tidak boleh digunakan untuk pengawatan dalam.

- Konduktor serabut yang dikenai tekanan pada proses penyambungan tidak boleh disolder kecuali menggunakan clamping yang tidak menimbulkan resiko kontak saat proses solderan menjadi dingin 
Metode dan teknik pengukuran untuk kekuatan dielektrik bahan isolasi :

- Siapkan sampel uji dengan memotong semua konduktor kabel yang hanya berisolasi dasar pada pengawatan dalam (kira-kira $10 \mathrm{~cm}$ ).

- Tempelkan alumunium foil pada semua permukaan isolasinya pada sampel tersebut.

- Buatlah rangkaian seperti gambar 2 berikut ;

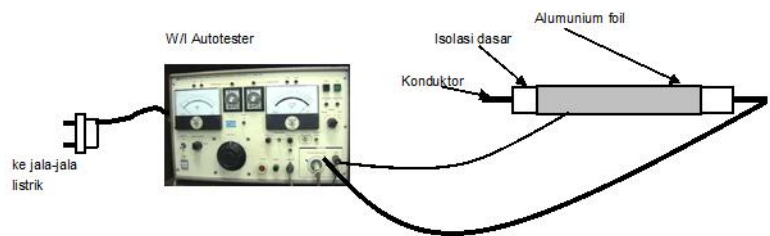

Gambar 2. Rangkaian pengujian ketahanan dielektrik

- Operasikan W/I Autotester dengan setingan cut off arus $100 \mathrm{~mA}$ dan waktu 15 menit dengan tegangan AC $2000 \mathrm{~V}$.

- Tekan tombol test pada W/I Autotester kemudian biarkan sampai suara buzer berbunyi. Apabila buzer berbunyi sebelum waktu 15 menit maka terjadi tembus tegangan pada konduktor kabel tersebut

Metode dan teknik pengukuran untuk pengukuran luas penampang konduktor :

- Pengukuran dengan menggunakan vernier caliper terhadap diameter konduktor kabel suplai seperti gambar 3.

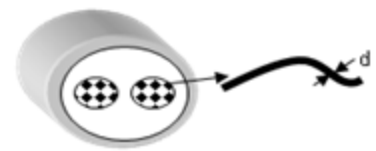

Gambar 3. Pengukuran diameter

- Hitunglah luas penampang konduktor dengan menggunakan rumus berikut :

$A=\frac{\pi}{4} d^{2}$

- Bandingkan hasil pengukuran dengan tabel 1 berikut ini

TABEL I. LUAS PENAMPANG MINIMUM KONDUKTOR

\begin{tabular}{|c|c|}
\hline Arus pengenal piranti (A) & $\begin{array}{c}\text { Luas penampang nominal } \\
\left(\mathrm{mm}^{2}\right)\end{array}$ \\
\hline$<0,2$ & Senur pilin \\
\hline$>0,2$ dan $\leq 3$ & $0,5^{\mathrm{a}}$ \\
\hline$>3$ dan $\leq 6$ & 0,75 \\
\hline$>6$ dan $\leq 10$ & $1(0,75)^{\mathrm{b}}$ \\
\hline$>10$ dan $\leq 16$ & $1,5(1,0)^{\mathrm{b}}$ \\
\hline$>16$ dan $\leq 25$ & 2,5 \\
\hline$>25$ dan $\leq 32$ & 4 \\
\hline$>32$ dan $\leq 40$ & 6 \\
\hline$>20$ dan $\leq 63$ & 10 \\
\hline $\begin{array}{c}\text { a Senur ini mungkin hanya dapat digunakan jika } \\
\text { panjangnya tidak melebihi } 2 \text { meter antara titik dimana }\end{array}$ \\
\hline \multicolumn{2}{|c|}{}
\end{tabular}

senur atau pelindung senur masuk peranti dan masukan tusuk kontak

b Senur yang memiliki luas penampang yang ditunjukkan dalam tanda kurung dapat digunakan untuk peranti portabel jika panjangnya tidak melebihi $2 \mathrm{~m}$.

Metode dan teknik pengukuran untuk uji tarik dan torsi pada kabel fleksibel eksternal :

- Buat tanda dengan jarak kira - kira $20 \mathrm{~mm}$ dari stoper cord atau titik lain yang tersedia seperti gambar 4 .

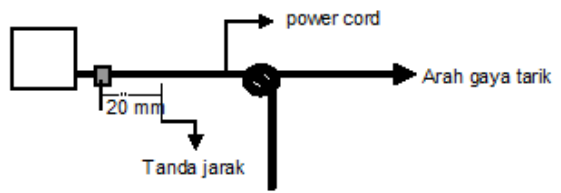

Gambar 4. Arah uji tarik

- Tarik kabel suplai dengan gaya sesuai dengan tabel 2 sebanyak 25 kali, selama 1 detik pada masing - masing tarikan dengan arah yang tidak menguntungkan dan penarikan tidak boleh ada hentakan.

TABEL II. GAYA TARIK DAN TORSI

\begin{tabular}{|c|c|c|}
\hline Massa peranti $(\mathrm{kg})$ & Gaya tarik $(\mathrm{N})$ & Torsi $(\mathrm{Nm})$ \\
\hline$\leq 1$ & 30 & 0,1 \\
\hline$>1$ dan $\leq 4$ & 60 & 0,25 \\
\hline$>4$ & 100 & 0,35 \\
\hline
\end{tabular}

- Uji gaya torsi pada sampel uji dengan torsi seperti pada tabel 2 selama satu menit seperti gambar 5

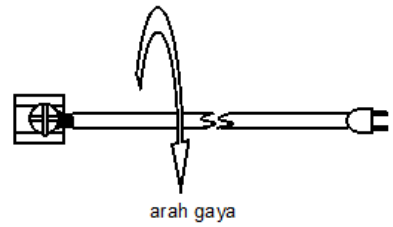

Gambar 5. Arah uji torsi

- Setelah selesai ukur pergeseran pada kabel power suplai dan pergeseran antara konduktor kabel suplai dengan terminal seperti gambar 6

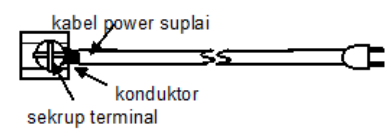

Gambar 6. Pengukuran pergeseran kabel

\section{HASIL DAN PEMBAHASAN}

Pada penulisan ini menggunakan berberapa sampel piranti peralatan listrik rumah tangga antara lain kipas angin, pompa listrik dan seterika listrik. Data dari sampel atau contoh uji pada kipas angin sesuai tabel 3, pompa air sesuai tabel 4 dan seterika listrik sesuai tabel 5. 
TABEL III. DATA HASIL PENGUJIAN PADA KIPAS ANGIN

\begin{tabular}{|c|c|c|c|c|c|c|c|c|c|}
\hline \multirow[t]{2}{*}{ No } & \multirow{2}{*}{$\begin{array}{l}\text { Model } \\
\text { kipas } \\
\text { angin / } \\
\text { Daya }\end{array}$} & \multicolumn{3}{|c|}{$\begin{array}{l}\text { Inspeksi Konduktor pada } \\
\text { Pengawatan Dalam }\end{array}$} & \multirow{2}{*}{$\begin{array}{c}\text { Kekuatan } \\
\text { Dielektrik } \\
100 \mathrm{~mA}, \\
2000 \mathrm{~V}, \\
15 \text { menit }\end{array}$} & \multicolumn{2}{|c|}{$\begin{array}{c}\text { Luas Penampang } \\
\text { Konduktor }\end{array}$} & \multicolumn{2}{|c|}{$\begin{array}{c}\text { Uji Tarik Kabel } \\
\text { Fleksibel Eksternal }\end{array}$} \\
\hline & & $\begin{array}{c}\text { Bagian } \\
\text { tajam / } \\
\text { bergerak } \\
\text { / panas }\end{array}$ & $\begin{array}{c}\text { Standar } \\
\text { Kabel }\end{array}$ & $\begin{array}{c}\text { Tidak } \\
\text { disolder } \\
\text { kecuali } \\
\text { clamping }\end{array}$ & & $\begin{array}{l}\text { Diameter / } \\
\text { jumlah } \\
\text { serabut } \\
\text { konduktor }\end{array}$ & $\begin{array}{l}\text { Luas } \\
\mathrm{mm}^{2}\end{array}$ & $\begin{array}{c}\text { Berat piranti } \\
(\mathrm{kg}) / \text { Gaya } \\
\text { Tarik (N)/ } \\
\text { Torsi (Nm) }\end{array}$ & $\begin{array}{l}\text { Pergese- } \\
\text { ran } \\
\text { kabel } \\
(\mathrm{mm})\end{array}$ \\
\hline 1 & $\begin{array}{l}\text { Berdiri / } \\
50 \text { Watt }\end{array}$ & $\sqrt{ }$ & IEC 53 & $\sqrt{ }$ & $\begin{array}{l}\text { Tidak } \\
\text { tembus }\end{array}$ & $0,19 / 20$ & 0,566 & $\begin{array}{c}3,20 / \\
100 / 0,35\end{array}$ & 1,72 \\
\hline 2 & $\begin{array}{l}\text { Berdiri / } \\
55 \text { Watt }\end{array}$ & $\sqrt{ }$ & IEC 53 & $\sqrt{ }$ & $\begin{array}{l}\text { Tidak } \\
\text { tembus }\end{array}$ & $0,19 / 20$ & 0,566 & $\begin{array}{c}3,44 / \\
100 / 0,35\end{array}$ & 7,15 \\
\hline 3 & $\begin{array}{l}\text { Dinding / } \\
40 \text { watt }\end{array}$ & $\sqrt{ }$ & IEC 52 & $\sqrt{ }$ & $\begin{array}{l}\text { Tidak } \\
\text { tembus }\end{array}$ & $0,18 / 20$ & 0,508 & $\begin{array}{c}2,8 / \\
60 / 0,25\end{array}$ & 1,40 \\
\hline 4 & $\begin{array}{l}\text { Dinding / } \\
45 \text { watt }\end{array}$ & $\sqrt{ }$ & IEC 52 & $\mathrm{X}$ & $\begin{array}{l}\text { Tidak } \\
\text { tembus }\end{array}$ & $0,18 / 20$ & 0,508 & $\begin{array}{c}2,6 / \\
60 / 0,25\end{array}$ & 1,52 \\
\hline 5 & $\begin{array}{l}\text { Kotak / } \\
40 \text { watt }\end{array}$ & $\sqrt{ }$ & IEC 52 & $\sqrt{ }$ & $\begin{array}{c}\text { Tidak } \\
\text { tembus }\end{array}$ & $0,18 / 20$ & 0,508 & $\begin{array}{c}2,5 / \\
60 / 0,25\end{array}$ & 1,10 \\
\hline 6 & $\begin{array}{l}\text { Kotak / } \\
35 \text { watt }\end{array}$ & $\sqrt{ }$ & IEC 52 & $\sqrt{ }$ & $\begin{array}{c}\text { Tidak } \\
\text { tembus }\end{array}$ & $0,18 / 20$ & 0,508 & $\begin{array}{c}2,3 / \\
60 / 0,25\end{array}$ & 1,35 \\
\hline 7 & $\begin{array}{l}\text { Duduk / } \\
25 \text { watt } \\
\end{array}$ & $\sqrt{ }$ & $\begin{array}{c}\text { Tidak } \\
\text { ada }\end{array}$ & $\sqrt{ }$ & $\begin{array}{l}\text { Tidak } \\
\text { tembus }\end{array}$ & $0,16 / 19$ & 0,361 & $\begin{array}{c}1,8 / \\
60 / 0,25\end{array}$ & 12,40 \\
\hline 8 & $\begin{array}{l}\text { Duduk / } \\
30 \text { watt }\end{array}$ & $\sqrt{ }$ & IEC 52 & $\sqrt{ }$ & $\begin{array}{c}\text { Tidak } \\
\text { tembus }\end{array}$ & $0,18 / 20$ & 0,508 & $\begin{array}{c}2,3 / \\
60 / 0,25 \\
\end{array}$ & 1,35 \\
\hline 9 & $\begin{array}{c}\text { Tornado/ } \\
75 \text { watt }\end{array}$ & $\sqrt{ }$ & IEC 53 & $\sqrt{ }$ & $\begin{array}{c}\text { Tidak } \\
\text { tembus }\end{array}$ & $0,18 / 20$ & 0,508 & $\begin{array}{c}4,10 / \\
100 / 0,35 \\
\end{array}$ & 1,50 \\
\hline 10 & $\begin{array}{l}\text { Atap / } \\
65 \text { watt }\end{array}$ & $\sqrt{ }$ & IEC 53 & $\sqrt{ }$ & $\begin{array}{l}\text { Tidak } \\
\text { tembus }\end{array}$ & $0,19 / 20$ & 0,566 & $\begin{array}{c}3,84 / \\
100 / 0,35\end{array}$ & 1,50 \\
\hline
\end{tabular}

Berdasarkan tabel 3 diatas menunjukkan bahwa :

- Baris yang terasir warna gelap menunjukkan piranti ke 2, 4 dan 7 tidak memenuhi persyaratan SNI IEC 60335-1:2009 dan SNI IEC 60335-2-80:2009 sehingga dinyatakan gagal dalam pengujian

- Faktor penyebab kegagalan pengujian pada piranti 2 dan 7 adalah tidak adanya jangkar kabel yang mampu menahan tarikan pada penggunaan normal sehingga pergeseran kabel > $2 \mathrm{~mm}$ seperti gambar 7(a) dan 7(b). Sedangkan faktor penyebab kegagalan uji pada piranti 4 adalah pengawatan dalam pada konduktor pembawa arus pada kabel suplai langsung disolder tanpa clamping seperti gambar 7(c) sehingga dimungkinkan terjadi hubung singkat

- Perbaikan piranti bisa dilakukan dengan pemasangan jangkar kabel yang kuat terhadap tarikan seperti gambar 7(d) dan memperhatikan konduktor pembawa arus untuk di clamping sehingga aman dalam penggunaannya.

- Hal yang perlu diperhatikan pada pengkabelan untuk kipas angin adalah kabel suplai yang terpasang harus sesuai dengan standard yang berlaku yaitu IEC 52 (berat piranti $<3 \mathrm{~kg}$ ) atau IEC 53 (berat piranti $>3 \mathrm{~kg}$ ) seperti gambar 7(e). Biasanya kabel suplai IEC 52 digunakan pada kipas angin model duduk, dinding dan kotak sedangkan kabel IEC 53 digunakan pada kipas angin model berdiri, tornado dan atap. Kabel suplai yang sesuai standard IEC 52 atau IEC 53 mempunyai luas penampang minimal $0,5 \mathrm{~mm}^{2}$ dengan jumlah serabut konduktor minimal 20 dan diameter tiap serabut konduktor minimal $0,18 \mathrm{~mm}$. 


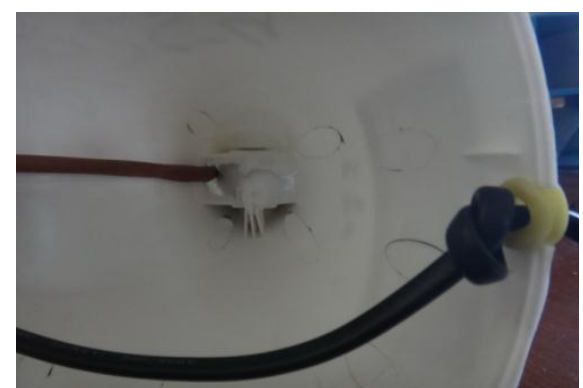

(a)

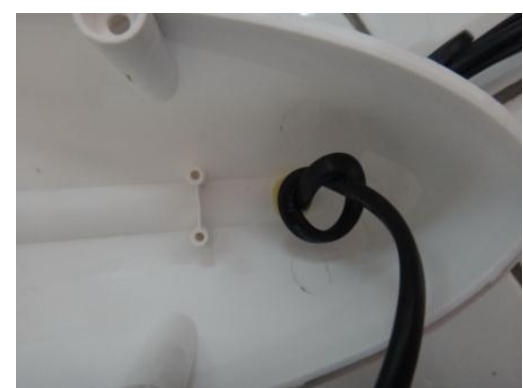

(b)

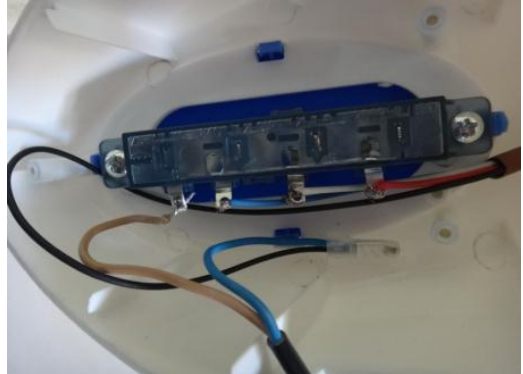

(c)

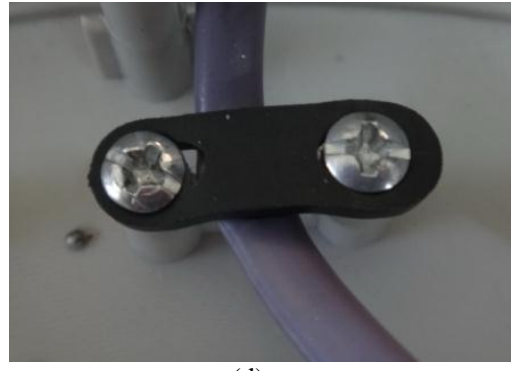

(d)

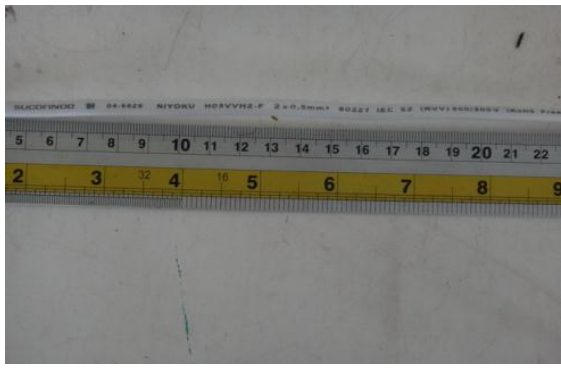

(e)

Gambar 7. Faktor penyebab kegagalan dan perbaikannya pada kipas angin

TABEL IV. DATA HASIL PENGUJIAN PADA POMPA AIR

\begin{tabular}{|c|c|c|c|c|c|c|c|c|c|}
\hline \multirow[t]{2}{*}{ No } & \multirow{2}{*}{$\begin{array}{c}\text { Daya } \\
\text { pompa } \\
\text { air (watt) }\end{array}$} & \multicolumn{3}{|c|}{$\begin{array}{c}\text { Inspeksi Konduktor pada } \\
\text { Pengawatan Dalam }\end{array}$} & \multirow{2}{*}{$\begin{array}{c}\text { Kekuatan } \\
\text { Dielektrik } \\
100 \mathrm{~mA}, \\
2000 \mathrm{~V}, \\
15 \text { menit }\end{array}$} & \multicolumn{2}{|c|}{$\begin{array}{c}\text { Luas Penampang } \\
\text { Konduktor }\end{array}$} & \multicolumn{2}{|c|}{$\begin{array}{c}\text { Uji Tarik Kabel } \\
\text { Fleksibel Eksternal }\end{array}$} \\
\hline & & $\begin{array}{c}\text { Bagian } \\
\text { tajam / } \\
\text { bergerak } \\
\text { / panas }\end{array}$ & $\begin{array}{c}\text { Standar } \\
\text { Kabel }\end{array}$ & $\begin{array}{c}\text { Tidak } \\
\text { disolder } \\
\text { kecuali } \\
\text { clamping }\end{array}$ & & $\begin{array}{c}\text { Diameter / } \\
\text { jumlah } \\
\text { serabut } \\
\text { konduktor }\end{array}$ & $\begin{array}{l}\text { Luas } \\
\mathrm{mm}^{2}\end{array}$ & $\begin{array}{c}\text { Berat piranti } \\
(\mathrm{kg}) / \text { Gaya } \\
\text { Tarik }(\mathrm{N}) / \\
\text { Torsi }(\mathrm{Nm})\end{array}$ & $\begin{array}{c}\text { Pergese- } \\
\text { ran } \\
\text { kabel } \\
(\mathrm{mm})\end{array}$ \\
\hline 1 & 300 & $\sqrt{ }$ & $\begin{array}{l}\text { Tidak } \\
\text { ada }\end{array}$ & $\sqrt{ }$ & $\begin{array}{l}\text { Tidak } \\
\text { tembus }\end{array}$ & $0,19 / 22$ & 0,623 & $\begin{array}{c}3,20 / \\
100 / 0,35\end{array}$ & 4,20 \\
\hline 2 & 350 & $\sqrt{ }$ & IEC 57 & $\sqrt{ }$ & $\begin{array}{l}\text { Tidak } \\
\text { tembus }\end{array}$ & $0,20 / 24$ & 0,753 & $\begin{array}{c}3,20 / \\
100 / 0,35\end{array}$ & 1,62 \\
\hline 3 & 350 & $\sqrt{ }$ & IEC 57 & $\sqrt{ }$ & $\begin{array}{l}\text { Tidak } \\
\text { tembus }\end{array}$ & $0,20 / 24$ & 0,753 & $\begin{array}{c}3,20 / \\
100 / 0,35\end{array}$ & 2,76 \\
\hline 4 & 400 & $\sqrt{ }$ & IEC 57 & $\sqrt{ }$ & $\begin{array}{l}\text { Tidak } \\
\text { tembus }\end{array}$ & $0,20 / 24$ & 0,753 & $\begin{array}{c}3,40 / \\
100 / 0,35\end{array}$ & 1,80 \\
\hline 5 & 400 & $\sqrt{ }$ & IEC 57 & $\sqrt{ }$ & $\begin{array}{l}\text { Tidak } \\
\text { tembus }\end{array}$ & $0,20 / 24$ & 0,753 & $\begin{array}{c}3,20 / \\
100 / 0,35\end{array}$ & 3,30 \\
\hline 6 & 425 & $\sqrt{ }$ & IEC 57 & $\sqrt{ }$ & $\begin{array}{l}\text { Tidak } \\
\text { tembus }\end{array}$ & $0,20 / 24$ & 0,753 & $\begin{array}{c}3,70 / \\
100 / 0,35\end{array}$ & 1,48 \\
\hline 7 & 450 & $\sqrt{ }$ & IEC 57 & $\sqrt{ }$ & $\begin{array}{l}\text { Tidak } \\
\text { tembus }\end{array}$ & $0,20 / 24$ & 0,753 & $\begin{array}{c}3,75 / \\
100 / 0,35\end{array}$ & 1,22 \\
\hline 8 & 550 & $\sqrt{ }$ & IEC 57 & $\sqrt{ }$ & $\begin{array}{l}\text { Tidak } \\
\text { tembus }\end{array}$ & $0,20 / 24$ & 0,753 & $\begin{array}{c}4,85 / \\
100 / 0,35\end{array}$ & 1,30 \\
\hline 9 & 600 & $\sqrt{ }$ & IEC 57 & $\sqrt{ }$ & $\begin{array}{l}\text { Tidak } \\
\text { tembus }\end{array}$ & $0,22 / 25$ & 0,785 & $\begin{array}{c}5,15 / \\
100 / 0,35\end{array}$ & 1,00 \\
\hline 10 & 800 & $\sqrt{ }$ & IEC 57 & $\sqrt{ }$ & $\begin{array}{l}\text { Tidak } \\
\text { tembus }\end{array}$ & $0,23 / 24$ & 0,996 & $\begin{array}{c}6,18 / \\
100 / 0,35\end{array}$ & 0,90 \\
\hline
\end{tabular}

Berdasarkan tabel 4 diatas menunjukkan bahwa :

- Baris yang terasir warna gelap menunjukkan piranti ke 1, 3 dan 5 tidak memenuhi persyaratan SNI IEC 60335-1:2009 dan SNI IEC 60335-2-41:2009 sehingga dinyatakan gagal dalam pengujian
- Faktor penyebab kegagalan pengujian pada piranti 3 adalah pemasangan dan posisi jangkar kabel yang kurang tepat dan masih mudah longgar biarpun telah mempunyai jangkar kabel tetapi tidak dilengkapi bushing di tutup terminal pada jalan keluarnya kabel suplai seperti gambar 
8(a). Sedangkan pada piranti 5 disebabkan kabel suplai hanya di clamper saja tanpa ikatan jangkar biarpun terdapat bushing pada penutup terminal seperti gambar 8(b). Pada piranti 1 dikarenakan tidak menggunakan kabel suplai sesuai standard sehingga luas penampang konduktor tidak memadai untuk aliran arus listrik seperti gmbar 8(c)

- Perbaikan piranti bisa dilakukan dengan memberikan bushing pada penutup terminal sebagai perekat kabel suplai selain pemasangan jangkar kabel sehingga lebih kuat dan tahan terhadap tarikan pada seperti gambar $8(\mathrm{~d})$ atau memasang jangkar kabel dengan dilengkapi mur baut pada sisi kiri dan sisi kanan seperti gambar 8(e)

- Hal yang perlu diperhatikan pada pengkabelan untuk pompa air adalah kabel suplai yang terpasang harus sesuai dengan standard yang berlaku yaitu IEC 57 seperti gambar 8(f) sehingga mempunyai luas penampang minimal 0,75 $\mathrm{mm}^{2}$ dengan jumlah serabut konduktor minimal 24 dan diameter tiap serabut konduktor minimal $0,2 \mathrm{~mm}$.

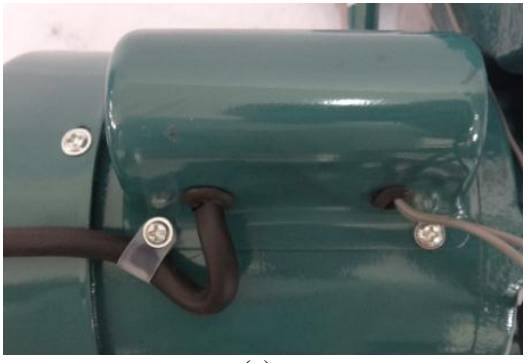

(a)

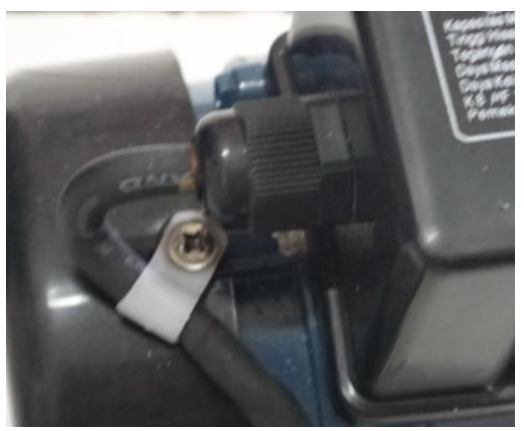

(d)

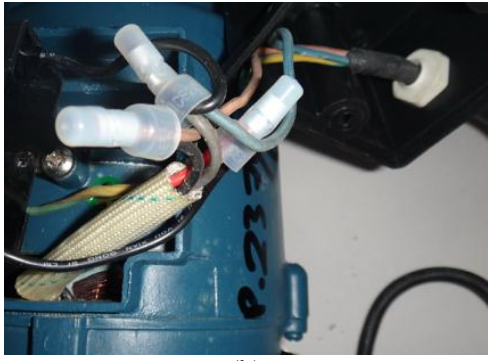

(b)

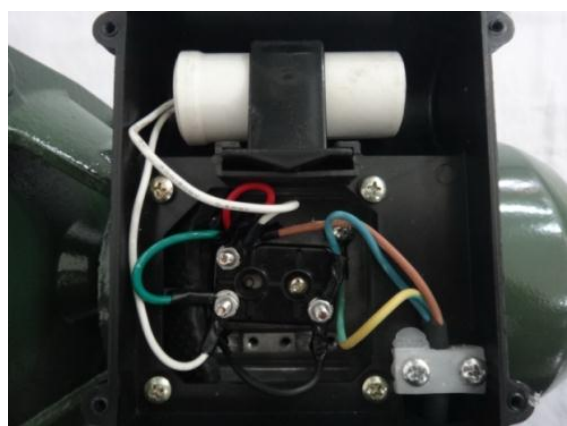

(e)

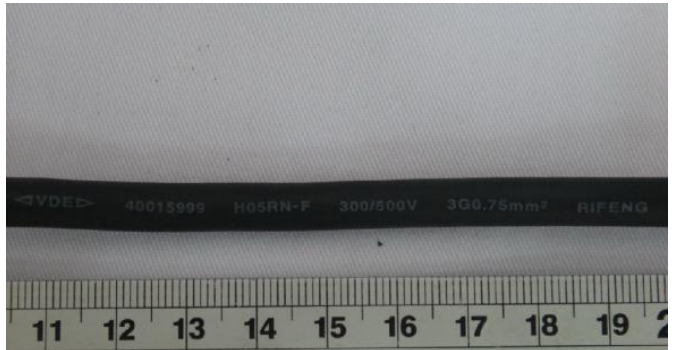

(c)

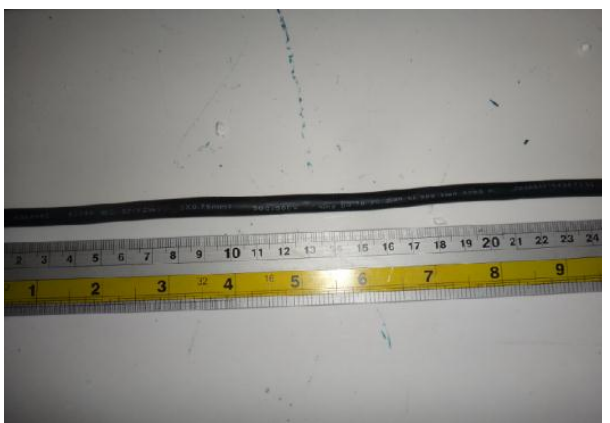

(f)

Gambar 8. Faktor penyebab kegagalan dan perbaikannya pada pompa air

TABEL V. DATA HASIL PENGUJIAN PADA SETERIKA LISTRIK

\begin{tabular}{|c|c|c|c|c|c|c|c|c|c|}
\hline \multirow[t]{2}{*}{ No } & \multirow{2}{*}{$\begin{array}{c}\text { Daya } \\
\text { seterika } \\
\text { listrik } \\
\text { (watt) }\end{array}$} & \multicolumn{3}{|c|}{$\begin{array}{l}\text { Inspeksi Konduktor pada } \\
\text { Pengawatan Dalam }\end{array}$} & \multirow{2}{*}{$\begin{array}{c}\text { Kekuatan } \\
\text { Dielektrik } \\
100 \mathrm{~mA}, \\
2000 \mathrm{~V}, \\
15 \text { menit }\end{array}$} & \multicolumn{2}{|c|}{$\begin{array}{c}\text { Luas Penampang } \\
\text { Konduktor }\end{array}$} & \multicolumn{2}{|c|}{$\begin{array}{c}\text { Uji Tarik Kabel } \\
\text { Fleksibel Eksternal }\end{array}$} \\
\hline & & $\begin{array}{c}\text { Bagian } \\
\text { tajam / } \\
\text { bergerak } \\
\text { / panas }\end{array}$ & $\begin{array}{c}\text { Standar } \\
\text { Kabel }\end{array}$ & $\begin{array}{c}\text { Tidak } \\
\text { disolder } \\
\text { kecuali } \\
\text { clamping } \\
\end{array}$ & & $\begin{array}{c}\text { Diameter / } \\
\text { jumlah } \\
\text { serabut } \\
\text { konduktor }\end{array}$ & $\begin{array}{l}\text { Luas } \\
\mathrm{mm}^{2}\end{array}$ & $\begin{array}{c}\text { Berat piranti } \\
(\mathrm{kg}) / \text { Gaya } \\
\text { Tarik }(\mathrm{N}) / \\
\text { Torsi }(\mathrm{Nm}) \\
\end{array}$ & $\begin{array}{c}\text { Pergese- } \\
\text { ran } \\
\text { kabel } \\
(\mathrm{mm}) \\
\end{array}$ \\
\hline 1 & 300 & $\sqrt{ }$ & $\begin{array}{l}\text { Senur } \\
\text { pilin }\end{array}$ & $\sqrt{ }$ & $\begin{array}{l}\text { Tidak } \\
\text { tembus }\end{array}$ & - & - & $\begin{array}{c}1,65 / \\
60 / 0,25\end{array}$ & 1,20 \\
\hline 2 & 350 & $\sqrt{ }$ & $\begin{array}{l}\text { Senur } \\
\text { pilin }\end{array}$ & $\sqrt{ }$ & $\begin{array}{l}\text { Tidak } \\
\text { tembus }\end{array}$ & - & - & $\begin{array}{c}1,65 / \\
60 / 0,25\end{array}$ & 0,72 \\
\hline 3 & 400 & $X$ & $\begin{array}{l}\text { Senur } \\
\text { pilin }\end{array}$ & $\sqrt{ }$ & $\begin{array}{l}\text { Tidak } \\
\text { tembus }\end{array}$ & - & - & $\begin{array}{c}1,65 / \\
60 / 0,25\end{array}$ & 1,10 \\
\hline 4 & 300 & $\sqrt{ }$ & $\begin{array}{l}\text { Senur } \\
\text { pilin }\end{array}$ & $\sqrt{ }$ & $\begin{array}{l}\text { Tidak } \\
\text { tembus }\end{array}$ & - & - & $\begin{array}{c}1,65 / \\
60 / 0,25\end{array}$ & 0,92 \\
\hline 5 & 395 & $\sqrt{ }$ & $\begin{array}{l}\text { Senur } \\
\text { pilin }\end{array}$ & $\sqrt{ }$ & $\begin{array}{l}\text { Tidak } \\
\text { tembus }\end{array}$ & - & - & $\begin{array}{c}1,65 / \\
60 / 0,25\end{array}$ & 1,12 \\
\hline 6 & 350 & $\sqrt{ }$ & $\begin{array}{l}\text { Senur } \\
\text { pilin }\end{array}$ & $\sqrt{ }$ & $\begin{array}{c}\text { Tidak } \\
\text { tembus }\end{array}$ & - & - & $\begin{array}{c}1,65 / \\
60 / 0,25 \\
\end{array}$ & 1,00 \\
\hline 7 & 400 & $\sqrt{ }$ & $\begin{array}{l}\text { Senur } \\
\text { pilin }\end{array}$ & $\sqrt{ }$ & $\begin{array}{l}\text { Tidak } \\
\text { tembus }\end{array}$ & - & - & $\begin{array}{c}1,65 / \\
60 / 0,25\end{array}$ & 1,42 \\
\hline 8 & 350 & $\sqrt{ }$ & Senur & $\sqrt{ }$ & Tidak & - & - & $1,65 /$ & 0,65 \\
\hline
\end{tabular}




\begin{tabular}{|c|c|c|c|c|c|c|c|c|c|}
\hline \multirow[t]{2}{*}{ No } & \multirow{2}{*}{$\begin{array}{c}\text { Daya } \\
\text { seterika } \\
\text { listrik } \\
\text { (watt) }\end{array}$} & \multicolumn{3}{|c|}{$\begin{array}{l}\text { Inspeksi Konduktor pada } \\
\text { Pengawatan Dalam }\end{array}$} & \multirow{2}{*}{$\begin{array}{c}\text { Kekuatan } \\
\text { Dielektrik } \\
100 \mathrm{~mA} \text {, } \\
2000 \mathrm{~V}, \\
15 \text { menit }\end{array}$} & \multicolumn{2}{|c|}{$\begin{array}{l}\text { Luas Penampang } \\
\text { Konduktor }\end{array}$} & \multicolumn{2}{|c|}{$\begin{array}{c}\text { Uji Tarik Kabel } \\
\text { Fleksibel Eksternal }\end{array}$} \\
\hline & & $\begin{array}{c}\text { Bagian } \\
\text { tajam / } \\
\text { bergerak } \\
\text { / panas }\end{array}$ & $\begin{array}{c}\text { Standar } \\
\text { Kabel }\end{array}$ & $\begin{array}{c}\text { Tidak } \\
\text { disolder } \\
\text { kecuali } \\
\text { clamping }\end{array}$ & & $\begin{array}{l}\text { Diameter / } \\
\text { jumlah } \\
\text { serabut } \\
\text { konduktor }\end{array}$ & $\begin{array}{l}\text { Luas } \\
\mathrm{mm}^{2}\end{array}$ & $\begin{array}{c}\text { Berat piranti } \\
(\mathrm{kg}) / \text { Gaya } \\
\text { Tarik (N) / } \\
\text { Torsi }(\mathrm{Nm})\end{array}$ & $\begin{array}{c}\text { Pergese- } \\
\text { ran } \\
\text { kabel } \\
(\mathrm{mm})\end{array}$ \\
\hline & & & pilin & & tembus & & & $60 / 0,25$ & \\
\hline 9 & 350 & $\sqrt{ }$ & $\begin{array}{c}\text { Senur } \\
\text { pilin }\end{array}$ & $\sqrt{ }$ & $\begin{array}{l}\text { Tidak } \\
\text { tembus }\end{array}$ & - & - & $\begin{array}{c}1,65 / \\
60 / 0,25\end{array}$ & 0,24 \\
\hline 10 & 400 & $\sqrt{ }$ & $\begin{array}{c}\text { Senur } \\
\text { pilin }\end{array}$ & $\sqrt{ }$ & $\begin{array}{l}\text { Tidak } \\
\text { tembus }\end{array}$ & - & - & $\begin{array}{c}1,65 / \\
60 / 0,25\end{array}$ & 1,14 \\
\hline
\end{tabular}

Berdasarkan tabel 5 diatas menunjukkan bahwa :

- Baris yang terasir warna gelap menunjukkan piranti ke 3 tidak memenuhi persyaratan SNI IEC 60335-1:2009 dan SNI IEC 60335-2-3:2009 sehingga dinyatakan gagal dalam pengujian

- Faktor penyebab kegagalan pengujian pada piranti 3 disebabkan pada piranti seterika listrik wajib insulasi kelas I sesuai Peraturan Dirjen IUBTT tentang Juknis No. 14 tahun 2012 [12]. Pada gambar 9(a) terlihat piranti tidak mempunyai konduktor pembumian. Selain itu konduktor pembawa langsung terikat mur baut yang memungkinkan terjadi panas atau dapat tersentuh bagian sekitar konduktor yang tajam.
- Perbaikan piranti bisa dilakukan dengan pergantian kabel suplai sesuai insulasi kelas I yang mempunyai konduktor pembumian dan terpasang jangkar kabel seperti gambar 9(b).

- Hal yang perlu diperhatikan pada pengkabelan untuk kipas angin adalah kabel suplai yang terpasang harus insulasi kelas I. Biasanya kabel suplai pada seterika listrik berupa senur pilin sehingga sesuai standard yang berlaku tidak melakukan pengukuran luas penampang kabel tetapi mempunyai braided cord atau selungkup kabel yang lentur dan tahan panas. Pemasangan jangkar kabel yang tepat dan konduktor pembawa arus sebaiknya di clamping seperti gambar 9(c).

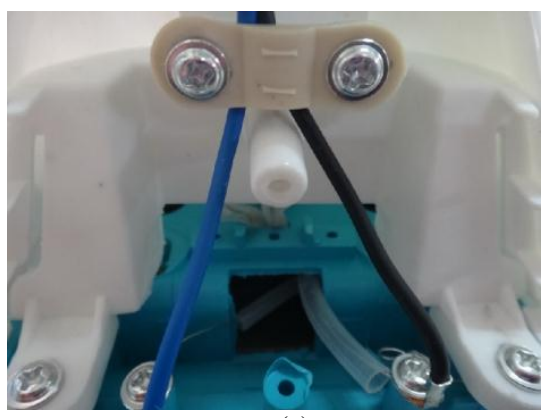

(a)

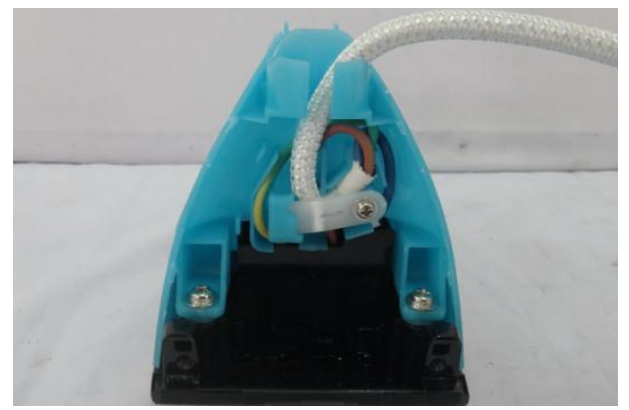

(b)

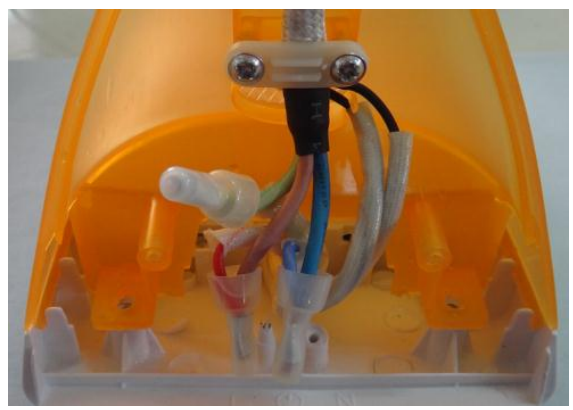

(c)

Gambar 9. Faktor penyebab kegagalan dan perbaikannya pada seterika listrik

\section{KESIMPULAN}

Inspeksi pengawatan dalam, uji kekuatan dielektrik bahan isolasi, pengukuran luas penampang konduktor, uji tarik dan torsi sesuai klausal 23 tentang pengkawatan internal dan klausal 25 tentang sambungan suplai dan senur fleksibel eksternal pada produk kipas angin, pompa air dan seterika listrik sesuai SNI IEC 60335-1:2009 menjadi parameter terhadap kualitas dan pemasangan kabel suplai pada peralatan rumah tangga pada penulisan ini. Pemakaian kabel harus sesuai standard sehingga tidak memenuhi luas penampang yang dipersyaratan. Pengawatan dalam harus terhindar bagian tajam, bergerak atau panas serta pemasangan konduktor pembawa arus yang tidak langsung disolder / mur baut untuk menghindari arus hubung singkat sehingga sebaiknya diclamping. Pemasangan jangkar kabel yang kuat terhadap gaya tarik dan torsi yang dipersyaratkan sehingga pergeseran kabel $<2$ mm sehingga aman dalam penggunaannya.

Kegagalan uji beberapa sampel kipas angin, pompa listrik dan seterika listrik pada penulisan ini banyak dipengaruhi oleh pemasangan jangkar kabel yang tidak kuat dan pemakaian standard kabel yang tidak sesuai dengan jenis dan berat piranti. Perbaikan piranti bisa dilakukan dengan memberikan bushing pada penutup terminal sebagai perekat kabel suplai selain pemasangan jangkar kabel sehingga lebih kuat dan tahan terhadap tarikan atau memasang jangkar kabel dengan dilengkapi mur baut pada sisi kiri dan sisi kanan serta penggunaan kabel suplai sesuai standard yang berlaku. 


\section{UCAPAN TERIMA KASIH}

Ucapan terima kasih saya sampaikan kepada laboratorium elektronika dan telematika pada Balai Riset dan Standardisasi Industri Surabaya atas fasilitas, bantuan, kerjasama dan dukungannya dalam proses penulisan ini.

\section{DAFTAR PUSTAKA}

[1] G. Firmansyah and T. Haryono, "Karakteristik berbagai jenis bahan isolasi kabel instalasi tegangan rendah," vol. 1, pp. 122-127, 2014.

[2] E. Suherman, E. Y. Astuty, and A. A. Budiman, "Analisis Produk Aman Perlengkapan Listrik Terpilih Untuk Keamanan Konsumen," Semin. Nas. Sains dan Teknol., no. November, 2015.

[3] A. Wibowo, P. Adinugroho, P. Penelitian, and B. S. Nasional, "Perlunya National Differences Dalam SNI Produk Tusuk Kontak Dan Kotak Kontak Needs of National Differences in SNI Plugs and Socket Outlets," pp. 67-74, 2015.

[4] N. Yuniarti and A. N. Afandi, "Tinjauan sifat hidrofobik bahan isolasi silicone rubber," Tekno, 1998.

[5] M. F. Dita, B. Widodo, F. Matematika, P. Alam, A. A. Model, A. Panas, A. A. Model, and P. Aliran,
"Karakteristik Aliran Panas dalam Logam," vol. 1, no. 1, pp. 1-5, 2013.

[6] H. Zikra Rufina , I Wayan Ratnata, "Analisis Tegangan Tembus Kabel Instalasi Listrik," Electrans, vol. 13, no. 1 Maret 2014, pp. 89-98, 2014.

[7] S. Totok Dermawan, Elin Nuraini, "Pengaruh komposisi resin terhadap sifat elektrik dan mekanik untuk bahan isolator tegangan tinggi," vol. 13 Januari, pp. 8-16, 2012.

[8] Badan Standardisasi Nasional, "Peranti listrik rumah tangga dan sejenis - Keselamatan - Bagian 1: Persyaratan umum," 2009.

[9] Badan Standardisasi Nasional, "Peranti listrik rumah tangga dan sejenis - Keselamatan - Bagian 2-80: Persyaratan khusus untuk kipas angin," 2009.

[10] Badan Standardisasi Nasional, "Peranti listrik rumah tangga dan sejenis - Keselamatan - Bagian 2-41: Persyaratan khusus untuk Pompa," 2009.

[11] Badan Standardisasi Nasional, "Peranti listrik rumah tangga dan sejenis - Keselamatan - Bagian 2-3: Persyaratan khusus untuk setrika listrik," 2009.

[12] Dirjen Kemenperin, "Juknis No.14_IUBTT_2012_.pdf." 2012. 